\title{
Light as a Broad-Spectrum Antimicrobial
}

\author{
Peter J. Gwynne* and Maurice P. Gallagher* \\ School of Biology, University of Edinburgh, Edinburgh, United Kingdom
}

Antimicrobial resistance is a significant and growing concern. To continue to treat even simple infections, there is a pressing need for new alternative and complementary approaches to antimicrobial therapy. One possible addition to the current range of treatments is the use of narrow-wavelength light as an antimicrobial, which has been shown to eliminate a range of common pathogens. Much progress has already been made with blue light but the potential of other regions of the electromagnetic spectrum is largely unexplored. In order that the approach can be fully and most effectively realized, further research is also required into the effects of energy dose, the harmful and beneficial impacts of light on eukaryotic tissues, and the role of oxygen in eliciting

\section{OPEN ACCESS}

Edited by:

Joshua D. Nosanchuk, Albert Einstein College of Medicine, United States

Reviewed by: Ludmila Baltazar, Universidade Federal de Minas Gerais, Brazil Sabine Szunerits, Lille University of Science and Technology, France

*Correspondence:

Peter J. Gwynne pgwynne@staffmail.ed.ac.uk Maurice P. Gallagher mp.gallagher@ed.ac.uk

Specialty section: This article was submitted to Antimicrobials, Resistance and Chemotherapy, a section of the journal

Frontiers in Microbiology

Received: 20 December 2017

Accepted: 18 January 2018

Published: 02 February 2018

Citation:

Gwynne PJ and Gallagher MP (2018)

Light as a Broad-Spectrum

Antimicrobial. Front. Microbiol. 9:119. doi: 10.3389/fmicb.2018.00119 microbial toxicity. These and other topics are discussed within this perspective.

Keywords: antimicrobials, infection, resistance, phototherapy, photosensitizers, blue light, ultraviolet, infrared

\section{INTRODUCTION}

The rise of antibiotic resistance has been (Jawetz, 1963; Lyon and Skurray, 1987; Neu, 1992) and continues to be (Goff et al., 2017; Manaia, 2017; Schroeder et al., 2017) extensively reported. Although new antibiotics are still being discovered (Ling et al., 2015; Zipperer et al., 2016), new discoveries are increasingly challenging and success in clinical trials is rare. In addition, the prevalence of pre-existing resistance systems in the environment (Bhullar et al., 2012), and the rapid rate of bacterial evolution (von Wintersdorff et al., 2016) mean that, even if adopted clinically, such compounds will only ever constitute a temporary reprieve. Thus, there is a clear need for alternative antimicrobial therapies which can be effective and sustainable in the longer term.

To prevent the emergence of resistance and to maximize treatment efficacy, novel therapies should ideally impact on a range of cellular targets. Whereas resistance to traditional antibiotics can arise through alteration of just a single amino acid residue in the antimicrobial target (Vila et al., 1994; Tsiodras et al., 2001), resistance becomes considerably less likely where a range of processes are targeted. The appeal of such a strategy is obvious and exemplified by broad-spectrum disinfectants (Russell, 2003).

Being widely found in a range of medical applications (Figure 1), electromagnetic radiation offers a promising avenue as an abiotic form of antimicrobial therapy. Currently two distinct light-mediated bactericidal techniques have been widely studied. The first of these, photodynamic therapy, has shown great potential against numerous pathogens and uses light of specific wavelength to stimulate an exogenously supplied photosensitizer, eliciting formation of toxic levels of reactive oxygen intermediates (Wainwright et al., 2016). In this perspective, we focus on the alternative approach in which light directly interacts with endogenous photosensitizers of the target microbe. This approach - eliminating the requirement for an additional third factor - removes a level of complexity in research, regulation, and application. It does, however, require a detailed knowledge of the interactions of biological systems (both prokaryotic and eukaryotic) with light. 


\section{THE PARADIGM OF BLUE LIGHT}

The 1903 Nobel Prize was awarded to Niels Ryberg Finsen for the use of blue light (Møller et al., 2005) in the treatment of tuberculosis of the skin. Having been largely neglected through the subsequent era of antibiotic discovery, interest in antimicrobial light was renewed toward the end of the 20th century. Blue light [typically 400-450 nm (Figure 1)], which is absorbed by porphyrins and is thought to cause cell death by the generation of toxic reactive oxygen species, has largely remained the focus of research since the 1980s (Kjeldstad and Johnsson, 1986; Koenig et al., 1992). While initial experiments required addition of exogenous porphyrins (Bertoloni et al., 1984; Nitzan et al., 1987) or enhancement of endogenous porphyrin production (Sailer et al., 1997; van der Meulen et al., 1997), it latterly became clear that natural levels of porphyrin are sufficient to elicit toxicity (Ashkenazi et al., 2003).

The bactericidal effect of blue light has been shown in many pathogenic species (Gupta et al., 2015; Halstead et al., 2016). Energy doses in the 10 or 100 s of $\mathrm{J} \mathrm{cm}^{-2}$ are typically sufficient to kill Staphylococcus aureus, for example (Maclean et al., 2008a; Halstead et al., 2016). Moreover, while few studies have rigorously explored the kinetics of killing using blue light, there appears to be a correlation between energy dose and reduction in viability, suggesting that total energy (rather than power, duration, or wavelength) is the major factor (Maclean et al., 2008b; Ramakrishnan et al., 2014).

The oxygen-dependence of the antimicrobial effect has been demonstrated repeatedly (Gourmelon et al., 1994; Feuerstein et al., 2005). However, experiments in a high-oxygen environment showed no additional benefit (Bumah et al., 2015), suggesting that oxygen availability does not limit toxicity. The limiting factor seems likely to be the concentration of absorptive porphyrins: efficacy can be enhanced by induction of porphyrin production, and toxicity in different species has been found to correlate with their accumulation of the pigment (Nitzan et al., 2004; Hamblin et al., 2005; Choi et al., 2011). More recent studies have investigated the precise contribution of different porphyrin species as well as other photosensitizers such as flavins and nicotinamides (Cieplik et al., 2014; Battisti et al., 2017; Kim and Yuk, 2017).

Oxidative damage may not be the sole cause of cell death, however. It has long been suggested that other mechanisms may contribute (Kjeldstad, 1987; Henry et al., 1995), and oxygen scavengers cannot completely protect against toxicity (Feuerstein et al., 2005; Maclean et al., 2008b). In addition to damage to protein and lipid components, infrared spectroscopy has revealed that DNA cleavage caused by blue light is similar to that seen in UVA-treated cells (Bumah et al., 2016), which is unsurprising given the spectral proximity of UVA and blue light (Figure 1). A completely different mechanism of toxicity was suggested by a recent transcriptomic study, which implicated the upregulation of phage proteins after irradiation (Yang et al., 2017). Inhibition of phage maturation completely prevented cell death, suggesting that this pathway (or components thereof) may be of great significance. A phage-dependent mechanism has important implications for antimicrobial selectivity, although may also limit the possible spectrum of targets.

\section{THERAPEUTIC POTENTIAL OF BLUE LIGHT}

While studies in the 1980s and 1990s typically focused on Propionibacterium acnes, recent research has been largely focused on Staphylococcus aureus. The immediate appeal of both organisms is their colonization of the skin, which is easily illuminated, although it is notable that one of the few published patient trials was carried out against Helicobacter pylori infection of the stomach (Lembo et al., 2009). While relatively little research has been translated into human clinical trials to date, animal models have been established (Yang et al., 2017; Zhu et al., 2017), demonstrating blue light killing of infecting cells a few hours after inoculation. These models are an encouraging development and further experiments showing successful treatment of an established infection featuring biofilm, persister cells, and intracellular bacteria will be a significant step toward clinical application.

Promisingly, however, reduction of cell numbers in established biofilms has been shown in vitro (Halstead et al., 2016; Wang et al., 2016). Tissue models also offer encouraging signs. Selectivity of the toxic effect for bacteria over mammalian cells has been demonstrated (Dai et al., 2013; Ramakrishnan et al., 2014). Different cell types appear variably tolerant to blue light, however: osteoblasts were killed above $36 \mathrm{~J} \mathrm{~cm}^{-2}$ whereas keratinocytes survived $>100 \mathrm{~J} \mathrm{~cm}^{-2}$. Given this difference in sensitivity across cell types, dose may have to be tailored depending on specific clinical application.

Currently few studies have investigated in detail the relationship between energy dose and killing. The available data (Maclean et al., 2008a, 2009; Endarko et al., 2012) suggest a sigmoidal dose-response curve implying that, as similarly observed with low-level oxidative stress (Kumar and Imlay, 2013), a sub-lethal light dose may be indefinitely tolerated by organisms with appropriate detoxifying systems. The existence of adaptive tolerance is supported by the finding that growth in low levels of blue light protects somewhat against subsequent highintensity challenge (Tomb et al., 2017). With repeated sub-lethal dosage, resistance to blue light has been reported (Guffey et al., 2013) although this point remains contentious (de Sousa N.T. et al., 2015; Tomb et al., 2017). The importance of appropriate dosing and considerations of light transmission through tissue are clearly of particular importance given that blue light can promote biofilm formation (Tschowri et al., 2009; Mussi et al., 2010). Further work to understand the mechanisms of killing and the dose-response relationships is needed to provide a quantitative basis for widespread and effective implementation.

Although therapeutic treatment of established infections may be the primary aim, preventative intervention may also be of value and more readily achievable. Toward this aim, extended exposure at low $(\mathrm{mW})$ power has been shown to slow bacterial growth (de Sousa D.L. et al., 2015; Ramakrishnan et al., 2016). The technology has also been trialed in a hospital setting, 


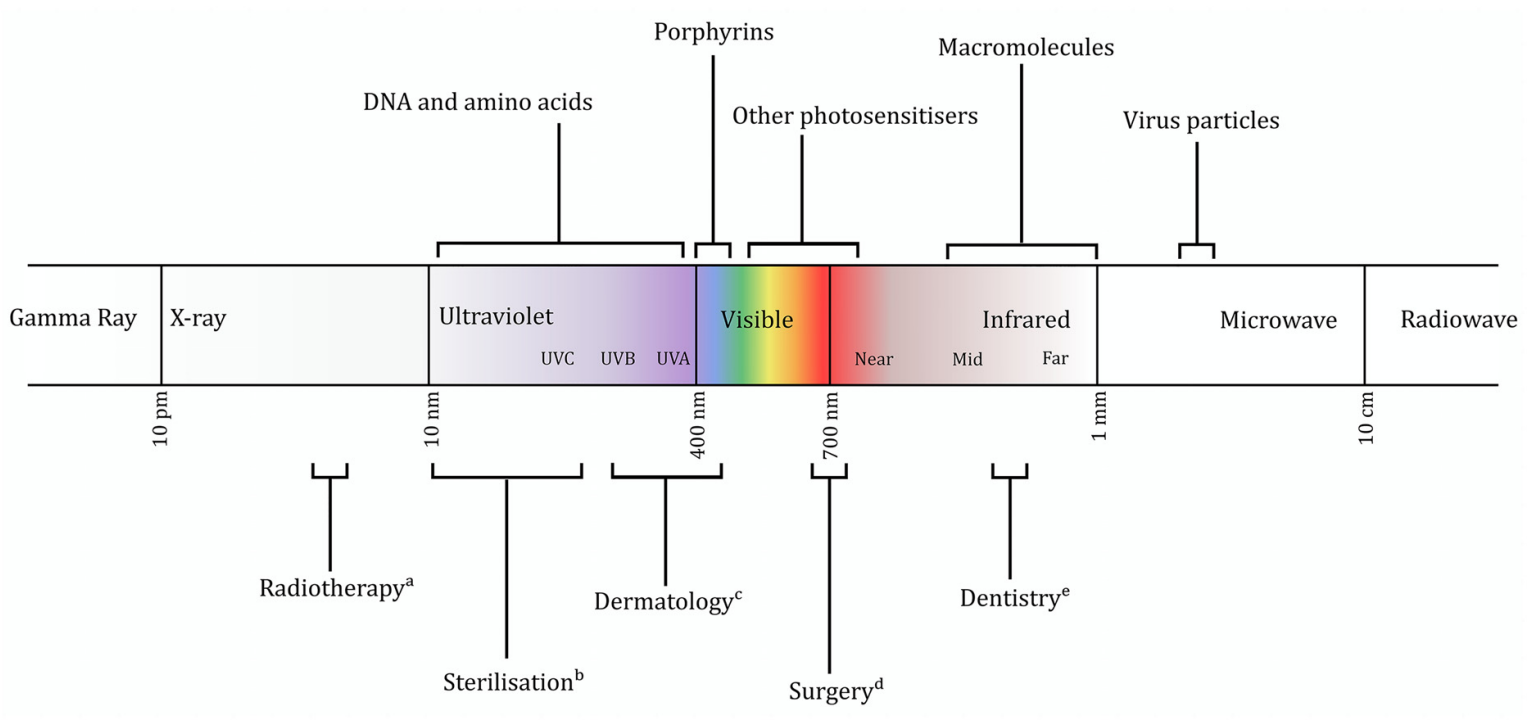

FIGURE 1 | Representation of the electromagnetic spectrum, with regions of interest discussed in the text indicated. Current applications of certain wavebands also shown. (a) (Hill et al., 2014); (b) (Chang et al., 1985); (c) (Tanzi et al., 2003); (d) (Jin et al., 2010); (e) (Cobb, 2006).

TABLE 1 | Optical properties of selected wavelengths in skin.

\begin{tabular}{lcccc}
\hline Wavelength $(\mathbf{n m})$ & $\begin{array}{c}\text { Absorption coefficient in } \\
\text { skin }\left(\mathbf{c m}^{-\mathbf{1}}\right)\end{array}$ & $\begin{array}{c}\text { Scattering coefficient in } \\
\text { skin }\left(\mathbf{c m}^{-\mathbf{1}}\right)\end{array}$ & $\begin{array}{c}\text { Approx penetration depth } \\
(\boldsymbol{\mu} \mathbf{m})\end{array}$ & $\begin{array}{l}\text { Major interactions in } \\
\text { tissue }\end{array}$ \\
\hline 300 & 45.0 & 260.0 & 6.0 & Mutagenic \\
350 & 25.0 & 220.0 & 60.0 & Mutagenic \\
400 & 13.5 & 34.3 & 90.0 & Mutagenic, photochemical \\
500 & 6.2 & 25.1 & 230.0 & Photochemical \\
600 & 3.8 & 18.6 & 550.0 & Photochemical \\
700 & 2.4 & 14.8 & 750.0 & Photochemical, thermal \\
800 & 1.9 & 12.4 & 1200.0 & Photochemical, thermal \\
1000 & 1.6 & 9.2 & 1600.0 & Thermal \\
1200 & 1.8 & 7.1 & 2200.0 & Thermal \\
\hline
\end{tabular}

In general, shorter wavelengths scatter and are absorbed more in tissues, limiting penetration depth. Data from Anderson and Parrish (1981) and Bashkatov et al. (2011).

producing modest reductions in bacterial counts on surfaces (Maclean et al., 2013).

\section{ALTERNATIVE PHOTOSENSITIZERS}

Several factors may complicate the widespread use of blue light. Sensitivity varies across species (Maclean et al., 2009) and has been shown to be dependent on the accumulation of particular intracellular porphyrins (Hamblin et al., 2005). Indeed, even within the same species, susceptibility can vary (Kim and Yuk, 2017) and both porphyrin accumulation and subsequent toxicity are affected by growth medium (Henry et al., 1995). Blue light is also absorbed strongly by many mammalian cell types, limiting its tissue penetration (Table 1) and therefore application to surface tissues. Additionally, mammalian cells have been shown to produce reactive oxygen under blue light illumination (Ramakrishnan et al., 2016), and singlet oxygen is a known mutagen (Hiraku et al., 2007), suggesting that power levels will require careful titration to avoid damage to tissues. Longer wavelengths, by contrast, are more readily transmissible.

Research on other parts of the electromagnetic spectrum is currently sparse but encouraging: Enterococcus (apparently resistant to blue light) has been shown to be sensitive to near- and mid-infrared (IR) light (Licata et al., 2015; D’Ercole et al., 2016), while the infectivity of Chlamydiaceae can be reduced with nearIR (Marti et al., 2015). Red light has been shown to reduce cell numbers in some pathogens (König et al., 2000; Martins et al., 2015; de Sousa et al., 2016), possibly due to the same porphyrin mechanism as blue light: porphyrins absorb most strongly in the blue region, but also absorb other visible wavelengths (Battisti et al., 2017). Additionally, infectivity of virus particles can be reduced by exposure to visible light (Richardson and Porter, 2005) Together, these data suggest that blue light is only one of a number of potential therapies, with the most obvious opportunities for development of antimicrobials exploiting other endogenous photosensitizers. 
Flavins (Eichner et al., 2015; Makdoumi et al., 2017) and vitamin A (El-Agamey et al., 2017) can both be photosensitized to produce reactive oxygen. Other possibilities exist in the visible range, however - there are examples of visible and IR-photoinduced production of oxygen species in prokaryotes (Kohli and Gupta, 2003; Lubart et al., 2011) and eukaryotes (Hayashi et al., 1997; Karu, 2008), suggesting that suitable chromophores exist, although they have yet to be identified. DNA damage in red- and nIR-irradiated Escherichia coli has been shown to require other cellular components, rather than occurring as a direct effect of light interacting with DNA (Rocha Teixeira et al., 2014; Martins et al., 2015). While the chromophores in these cases are unknown, there is also molecular evidence for light-mediated cell damage. Ferritin is excited by visible light and can modify numerous substrates including proteins (Nikandrov et al., 1997; Saenz et al., 2016). As well as porphyrin, other tetrapyrroles may also have potential. Vitamin $\mathrm{B} 12$ is known to absorb in the visible region (Wang et al., 2015), while hematoporphyrin is used as a photosensitizer (Tanaka et al., 2011).

One noteworthy example of this principle is in the use of green light to treat the fungal infection onychomycosis. Trichophyton rubrum, one of the causative agents, produces a characteristic red pigment xanthomegnin (Gupta et al., 2000) which can be targeted with $532 \mathrm{~nm}$ light, causing significant inhibition of growth (Vural et al., 2008). Numerous wavelengths in the visible and infrared have been used to treat onychomycosis with some success (Gupta and Versteeg, 2017). As is the case with the use of blue light against bacteria, there remains little consensus on the mechanism of toxicity, or the optimal treatment wavelength, power, or duration.

Food spoilage organisms such as Aspergillus and Phytophthora are often pigmented, which may allow similar selective targeting. A significant body of work exists regarding the use of light as a sterilizing agent in food and water processing (Song et al., 2016; Fan et al., 2017), much of it based around ultraviolet light. UV, however, also penetrates poorly (Table 1), limiting its application to surface decolonization. Although UV predominates, visible light wavelengths have also been suggested for application in the food industry (Imada et al., 2014; Gunther et al., 2016). Thus, other antimicrobial wavelengths may find use in a range of applications.

\section{OXYGEN-INDEPENDENT MECHANISMS}

The reliance on oxygen intermediates for toxicity may also limit the application of blue light, with deep tissues and biofilms often microaerophilic or anaerobic. Many pathogens also possess sophisticated, protective oxidative stress responses, which can contribute to virulence (Coady et al., 2015; Cheng et al., 2017). In Staphylococcus, the presence of antioxidant carotenoid pigments such as staphyloxanthin affects the killing efficiency of blue light (Halstead et al., 2016). Similar carotenoids are induced by exposure to blue light in Myxococcus (Galbis-Martínez et al., 2012). Again, the applicability of antimicrobial light would be enhanced by identification of wavelengths with oxygenindependent toxicity.

Despite the well-known dangers of UV, more recent results suggest that the waveband should not be overlooked. UVC, which directly results in DNA damage, has been shown to be a very effective antimicrobial, reducing cell numbers with as little as $2 \mathrm{~mJ} \mathrm{~cm}^{-2}$ (Dean et al., 2011). Clinical applications have been trialed, with ultraviolet lighting shown to reduce surgical site infections (Ritter et al., 2007). The full range of ultraviolet wavelengths is little explored, with most studies employing broad-band sources. Certain specific wavelengths have been reported to offer selectivity for bacteria over mammalian cells (Buonanno et al., 2013; Narita et al., 2018), highlighting the need for studies with greater wavelength resolution. UV's potent antimicrobial effect may be most easily applied to disinfection and sterilization, where patient compatibility is not required and positive results have already been seen (Anderson et al., 2017).

As well as DNA, bacterial proteins can be damaged irreversibly by UV light in a manner similar to that seen with oxidative damage (Bosshard et al., 2010). Other spectral bands may have similar effects, with exposure to green and red light altering protein folding, possibly by inducing reorganization of hydrogen bonds (Espinoza et al., 2015). Protein function can similarly be modulated by nIR light (Vojisavljevic et al., 2007), which in turn has been shown to cause DNA damage in plasmid DNA (Fonseca et al., 2012). Evidence for direct effects on cell components by wavelengths outside the ultraviolet range remains sparse, however, and the ubiquity of macromolecules such as DNA and protein may make selectivity against bacterial over host cells challenging (although potential targets exist). Metalloproteins (an emerging antibiotic target) may be potential targets here, being frequently virulence-associated and with characteristic absorbance properties (Dell'Acqua et al., 2011; Shumilina et al., 2014).

The killing mechanism of ultraviolet light is not entirely photochemical. Cells and spores have been shown to lyse under pulsed UV light as a result of localized transient temperature rise and water vaporization (Wekhof, 2000; Takeshita et al., 2003). The localized heating is dependent on higher absorption by the target cells than the surrounding environment (Fine and Gervais, 2004). In the case of UV light, DNA and amino acids are known to be absorptive chromophores, but other absorbers may also be identified. Successful development of this selective thermolysis approach depends on the identification of suitable bacterial chromophores and their activating wavelengths.

Biological macromolecules such as proteins (Barth, 2007), polysaccharides (Černá et al., 2003), and lipids (Hull et al., 2005) as well as small molecules (Amerov et al., 2004) all have characteristic absorbance spectra in the near- and midIR. Polysaccharides have broadly similar spectra but distinctive differences exist (Langkilde and Svantesson, 1995; Bekhit et al., 2016). Relatively minor chemical modifications can produce significant changes in absorbance (Hamcerencu et al., 2007), suggesting that the many variations found in bacterial capsules [E. coli alone has over 70 capsular subtypes (Whitfield, 2006)] may provide unique spectral differences to target. Indeed, 
bacteria (Tidwell et al., 2015; Almasoud et al., 2016) and fungi (Kogkaki et al., 2017) can be subtyped or differentiated from a eukaryotic host (Wang et al., 2010) by diagnostic fingerprint regions in their infrared spectra (Maity et al., 2013). Peptidoglycans, an obvious antimicrobial target, also have characteristic strain-specific spectra (Naumann et al., 1982). Such identifying peaks and regions, however, are by definition unique to particular species, suggesting that multiple therapeutic wavelengths could be required to maximize the range of possible target organisms.

Another approach to cellular disruption is the induction of damaging vibrational energy in the target. Such a disruption strategy may be of particular interest as an antiviral. The regular geometry of many viruses results in consistent vibrational frequencies (Dykeman and Sankey, 2010). If the intrinsic vibrational frequency of a viral particle is matched by that of an incident electromagnetic wave, the photons resonate and are absorbed, causing disruptive vibrations in the particle (Liu et al., 2009). This phenomenon can be exploited to destroy viruses with relatively low-powered microwave energy (Yang et al., 2015). It has been reported that very short (femtosecond) pulsed lasers can disrupt viruses and bacteria by a similar transfer of vibrational energy. The precise mechanisms underpinning this phenomenon are unclear, however, and findings to date have been inconsistent (Wigle et al., 2014) suggesting that considerable further work is required. Although not shown to reduce cell numbers, pulsed laser light has been shown to liberate biofilms from surfaces, possibly facilitating subsequent antibiotic therapy (Kizhner et al., 2011).

\section{PERSPECTIVES}

Blue light undoubtedly has the potential to become a highly effective antimicrobial. Key questions remain to be answered, however, including around the mechanisms of toxicity and in particular the contribution of porphyrin-independent mechanisms. Opportunities are not limited to widely studied blue light, necessitating the continued exploration of other antimicrobial wavelengths. The development of alternative or complementary methods is vital to expanding the range of target organisms and clinical applications, as well as to reducing the risk of the development of resistance. To maximize efficacy, a realistic light-based therapy seems likely to require use of multiple wavelengths with several distinct targets.

\section{REFERENCES}

Almasoud, N., Xu, Y., Ellis, D. I., Rooney, P., Turton, J. F., and Goodacre, R. (2016). Rapid discrimination of Enterococcus faecium strains using phenotypic analytical techniques. Anal. Methods 8, 7603-7613. doi: 10.1039/c6ay02 $326 f$

Amerov, A. K., Chen, J., and Arnold, M. A. (2004). Molar absorptivities of glucose and other biological molecules in aqueous solutions over the first overtone and combination regions of the near-infrared spectrum. Appl. Spectrosc. 58, 1195-1204. doi: 10.1366/0003702042336136

Anderson, D. J., Chen, L. F., Weber, D. J., Moehring, R. W., Lewis, S. S., Triplett, P. F., et al. (2017). Enhanced terminal room disinfection and acquisition
While other possibilities for therapies certainly exist, their development is limited at present by a paucity of knowledge regarding properties such as absorbance, reflectance, and scatter in biological systems. The fundamental optical properties of bacterial cell components and of cells are all vital to exploiting the physicochemical (and resultant biological) interactions between light and cells but currently only understood in the context of a few specific systems. Even among those studies involving antimicrobial light, most are focused on a handful of narrow wavebands (Kim et al., 2013; Kumar et al., 2016). Thus, the vast majority of the electromagnetic spectrum remains to be explored but holds tremendous potential. The required research may be built on existing techniques and knowledge. Spectroscopic techniques are improving rapidly and come with a wealth of data about the absorptive and scattering properties of cells, which could be of great value.

Development of an optimal treatment regime also represents a significant barrier to translating research into the clinic. Current studies differ widely in their exploration of wavelength, power, and treatment duration, with very few giving evidence of an empirical process of optimization. Nevertheless, two complementary modalities prevail. High-power, short-duration treatments could be used for directed therapy such as wound disinfection, together with the use of lower powers to reduce resident bacterial load in wards or operating theaters. Either case brings unique challenges in terms of the relationship between lethality and required energy dose, much of which are still only poorly understood. Although widespread use of antimicrobial light may be limited by such practicalities or issues of dose and administration, even limited clinical implementation will assist in prolonging the lifespan of existing antibiotics. Moreover, as our understanding of the underlying mechanisms develop, opportunities for other applications such as in agriculture and food production are likely to present themselves and may lead to technological transformations in these industries. However, in order to maximize such opportunities, further research into the underlying science is a necessary requirement.

\section{AUTHOR CONTRIBUTIONS}

All authors listed have made a substantial, direct, and intellectual contribution to the work, and approved it for publication.

and infection caused by multidrug-resistant organisms and Clostridium difficile (the Benefits of Enhanced Terminal Room Disinfection study): a cluster-randomised, multicentre, crossover study. Lancet 389, 805-814. doi: 10.1016/S0140-6736(16)31588-4

Anderson, R. R., and Parrish, J. A. (1981). The optics of human skin. J. Invest. Dermatol. 77, 13-19. doi: 10.1111/1523-1747.ep12479191

Ashkenazi, H., Malik, Z., Harth, Y., and Nitzan, Y. (2003). Eradication of Propionibacterium acnes by its endogenic porphyrins after illumination with high intensity blue light. FEMS Immunol. Med. Microbiol. 35, 17-24. doi: 10.1111/j.1574-695X.2003.tb00644.x

Barth, A. (2007). Infrared spectroscopy of proteins. Biochim. Biophys. Acta 1767, 1073-1101. doi: 10.1016/j.bbabio.2007.06.004 
Bashkatov, A. N., Genina, E. A., and Tuchin, V. V. (2011). Optical properties of skin, subcutaneous, and muscle tissues: a review. J. Innov. Opt. Health Sci. 04, 9-38. doi: 10.1142/S1793545811001319

Battisti, A., Morici, P., Ghetti, F., and Sgarbossa, A. (2017). Spectroscopic characterization and fluorescence imaging of Helicobacter pylori endogenous porphyrins. Biophys. Chem. 229, 19-24. doi: 10.1016/j.bpc.2017.05.010

Bekhit, M., Sánchez-González, L., Ben Messaoud, G., and Desobry, S. (2016). Design of microcapsules containing Lactococcus lactis subsp. lactis in alginate shell and xanthan gum with nutrients core. LWT Food Sci. Technol. 68, 446-453. doi: 10.1016/j.lwt.2015.12.037

Bertoloni, G., Salvato, B., Dall'Acqua, M., Vazzoler, M., and Jori, G. (1984). Hematoporphyrin-sensitised photoinactivation of Streptococcus faecalis. Photochem. Photobiol. 39, 811-816. doi: 10.1111/j.1751-1097.1984.tb08864.x

Bhullar, K., Waglechner, N., Pawlowski, A., Koteva, K., Banks, E. D., Johnston, M. D., et al. (2012). Antibiotic resistance is prevalent in an isolated cave microbiome. PLOS ONE 7:e34953. doi: 10.1371/journal.pone.0034953

Bosshard, F., Riedel, K., Schneider, T., Geiser, C., Bucheli, M., and Egli, T. (2010). Protein oxidation and aggregation in UVA-irradiated Escherichia coli cells as signs of accelerated cellular senescence. Environ. Microbiol. 12, 2931-2945. doi: 10.1111/j.1462-2920.2010.02268.x

Bumah, V. V., Aboualizadeh, E., Masson-Meyers, D. S., Eells, J. T., Enwemeka, C. S., and Hirschmugl, C. J. (2016). Spectrally resolved infrared microscopy and chemometric tools to reveal the interaction between blue light $(470 \mathrm{~nm})$ and methicillin-resistant Staphylococcus aureus. J. Photochem. Photobiol. B 167, 150-157. doi: 10.1016/j.jphotobiol.2016.12.030

Bumah, V. V., Whelan, H. T., Masson-Meyers, D. S., Quirk, B., Buchmann, E., and Enwemeka, C. S. (2015). The bactericidal effect of $470 \mathrm{~nm}$ light and hyperbaric oxygen on methicillin-resistant Staphylococcus aureus (MRSA). Lasers Med. Sci. 30, 1153-1159. doi: 10.1007/s10103-015-1722-9

Buonanno, M., Randers-Pehrson, G., Bigelow, A. W., Trivedi, S., Lowy, F. D., Spotnitz, H. M., et al. (2013). 207-nm UV light - a promising tool for safe lowcost reduction of surgical site infections. I: in vitro studies. PLOS ONE 8:e76968. doi: 10.1371/journal.pone.0076968

Černá, M., Barros, A. S., Nunes, A., Rocha, S. M., Delgadillo, I., Čopíková, J., et al. (2003). Use of FT-IR spectroscopy as a tool for the analysis of polysaccharide food additives. Carbohydr. Polym. 51, 383-389. doi: 10.1016/S0144-8617(02) 00259-X

Chang, J. C., Ossoff, S. F., Lobe, D. C., Dorfman, M. H., Dumais, C. M., Qualls, R. G., et al. (1985). UV inactivation of pathogenic and indicator microorganisms. Appl. Environ. Microbiol. 49, 1361-1365.

Cheng, C., Dong, Z., Han, X., Wang, H., Jiang, L., Sun, J., et al. (2017). Thioredoxin A is essential for motility and contributes to host infection of Listeria monocytogenes via redox interactions. Front. Cell. Infect. Microbiol. 7:287. doi: 10.3389/fcimb.2017.00287

Choi, M. S., Yun, S. J., Beom, H. J., Park, H. R., and Lee, J. B. (2011). Comparative Study of the bactericidal effects of 5-aminolevulinic acid with blue and red light on Propionibacterium acnes. J. Dermatol. 38, 661-666. doi: 10.1111/j.1346-8138. 2010.01094.x

Cieplik, F., Späth, A., Leibl, C., Gollmer, A., Regensburger, J., Tabenski, L., et al. (2014). Blue light kills Aggregatibacter actinomycetemcomitans due to its endogenous photosensitizers. Clin. Oral Investig. 18, 1763-1769. doi: 10.1007/ s00784-013-1151-8

Coady, A., Xu, M., Phung, Q., Cheung, T. K., Bakalarski, C., Alexander, M. K., et al. (2015). The Staphylococcus aureus ABC-type manganese transporter $\mathrm{MntABC}$ is critical for reinitiation of bacterial replication following exposure to phagocytic oxidative burst. PLOS ONE 10:e0138350. doi: 10.1371/journal.pone. 0138350

Cobb, C. M. (2006). Lasers in periodontics: a review of the literature. J. Periodontol. 77, 545-564. doi: 10.1902/jop.2006.050417

Dai, T., Gupta, A., Huang, Y.-Y., Yin, R., Murray, C. K., Vrahas, M. S., et al. (2013). Blue light rescues mice from potentially fatal Pseudomonas aeruginosa burn infection: efficacy, safety, and mechanism of action. Antimicrob. Agents Chemother. 57, 1238-1245. doi: 10.1128/AAC.01652-12

de Sousa, D. L., Lima, R. A., Zanin, I. C., Klein, M. I., Janal, M. N., and Duarte, S. (2015). Effect of twice-daily blue light treatment on matrix-rich biofilm development. PLOS ONE 10:e0131941. doi: 10.1371/journal.pone.0131941

de Sousa, N. T., Gomes, R. C., Santos, M. F., Brandino, H. E., Martinez, R., and de Jesus Guirro, R. R. (2016). Red and infrared laser therapy inhibits in vitro growth of major bacterial species that commonly colonize skin ulcers. Lasers Med. Sci. 31, 549-556. doi: 10.1007/s10103-016-1907-x

de Sousa, N. T., Santos, M. F., Gomes, R. C., Brandino, H. E., Martinez, R., and de Jesus Guirro, R. R. (2015). Blue laser inhibits bacterial growth of Staphylococcus aureus, Escherichia coli, and Pseudomonas aeruginosa. Photomed. Laser Surg. 33, 278-282. doi: 10.1089/pho.2014.3854

Dean, S. J., Petty, A., Swift, S., McGhee, J. J., Sharma, A., Shah, S., et al. (2011). Efficacy and safety assessment of a novel ultraviolet $\mathrm{C}$ device for treating corneal bacterial infections. Clin. Exp. Ophthalmol. 39, 156-163. doi: 10.1111/j.14429071.2010.02471.x

Dell'Acqua, S., Pauleta, S. R., Moura, I., and Moura, J. J. G. (2011). The tetranuclear copper active site of nitrous oxide reductase: the $\mathrm{CuZ}$ center. J. Biol. Inorg. Chem. 16, 183-194. doi: 10.1007/s00775-011-0753-3

D’Ercole, S., Spoto, G., Trentini, P., Tripodi, D., and Petrini, M. (2016). In vitro inactivation of Enterococcus faecalis with a LED Device. J. Photochem. Photobiol. B 160, 172-177. doi: 10.1016/j.jphotobiol.2016. 04.015

Dykeman, E. C., and Sankey, O. F. (2010). Atomistic modeling of the low-frequency mechanical modes and Raman spectra of icosahedral virus capsids. Phys. Rev. E 81:021918. doi: 10.1103/PhysRevE.81.021918

Eichner, A., Gollmer, A., Späth, A., Bäumler, W., Regensburger, J., König, B., et al. (2015). Fast and effective inactivation of Bacillus atrophaeus endospores using light-activated derivatives of vitamin B2. Photochem. Photobiol. Sci. 14, 387-396. doi: 10.1039/C4PP00285G

El-Agamey, A., Melø, T. B., and Sliwka, H.-R. (2017). Exploring the reactivity of retinol radical cation toward organic and biological molecules: a laser flash photolysis study. J. Photochem. Photobiol. B 170, 33-39. doi: 10.1016/j. jphotobiol.2017.03.009

Endarko, E., Maclean, M., Timoshkin, I. V., MacGregor, S. J., and Anderson, J. G. (2012). High-intensity $405 \mathrm{~nm}$ light inactivation of Listeria monocytogenes. Photochem. Photobiol. 88, 1280-1286. doi: 10.1111/j.1751-1097.2012. 01173.x

Espinoza, J. H., Reynaga-Hernández, E., Ruiz-García, J., Montero-Morán, G., Sanchez-Dominguez, M., and Mercado-Uribe, H. (2015). Effects of green and red light in $\beta \mathrm{L}$-crystallin and ovalbumin. Sci. Rep. 5:18120. doi: 10.1038/ srep 18120

Fan, X., Huang, R., and Chen, H. (2017). Application of ultraviolet C technology for surface decontamination of fresh produce. Trends Food Sci. Technol. 70, 9-19. doi: 10.1016/j.tifs.2017.10.004

Feuerstein, O., Ginsburg, I., Dayan, E., Veler, D., and Weiss, E. I. (2005). Mechanism of visible light phototoxicity on Porphyromonas gingivalis and Fusobacterium nucleatum. Photochem. Photobiol. 81, 1186-1189. doi: 10.1562/ 2005-04-06-RA-477

Fine, F., and Gervais, P. (2004). Efficiency of pulsed UV light for microbial decontamination of food powders. J. Food Prot. 67, 787-792. doi: 10.4315/0362028X-67.4.787

Fonseca, A. S., Geller, M., Filho, M. B., Valença, S. S., and de Paoli, F. (2012). Low-level infrared laser effect on plasmid DNA. Lasers Med. Sci. 27, 121-130. doi: 10.1007/s10103-011-0905-2

Galbis-Martínez, M., Padmanabhan, S., Murillo, F. J., and Elías-Arnanz, M. (2012). CarF mediates signaling by singlet oxygen, generated via photoexcited protoporphyrin IX, in Myxococcus xanthus light-induced carotenogenesis. J. Bacteriol. 194, 1427-1436. doi: 10.1128/JB.06662-11

Goff, D. A., Kullar, R., Goldstein, E. J. C., Gilchrist, M., Nathwani, D., Cheng, A. C., et al. (2017). A global call from five countries to collaborate in antibiotic stewardship: united we succeed, divided we might fail. Lancet Infect. Dis. 17, e56-e63. doi: 10.1016/S1473-3099(16)30386-3

Gourmelon, M., Cillard, J., and Pommepuy, M. (1994). Visible light damage to Escherichia coli in seawater: oxidative stress hypothesis. J. Appl. Bacteriol. 77, 105-112. doi: 10.1111/j.1365-2672.1994.tb03051.x

Guffey, J. S., Payne, W., Jones, T., and Martin, K. (2013). Evidence of resistance development by Staphylococcus aureus to an in vitro, multiple stage application of $405 \mathrm{~nm}$ light from a supraluminous diode array. Photomed. Laser Surg. 31, 179-182. doi: 10.1089/pho.2012.3450

Gunther, N. W., Phillips, J. G., and Sommers, C. (2016). The effects of 405$\mathrm{nm}$ visible light on the survival of Campylobacter on chicken skin and stainless steel. Foodborne Pathog. Dis. 13, 245-250. doi: 10.1089/fpd.2015. 2084 
Gupta, A. K., Ahmad, I., Borst, I., and Summerbell, R. C. (2000). Detection of xanthomegnin in epidermal materials infected with Trichophyton rubrum. J. Invest. Dermatol. 115, 901-905. doi: 10.1046/j.1523-1747.2000.00150.x

Gupta, A. K., and Versteeg, S. G. (2017). A critical review of improvement rates for laser therapy used to treat toenail onychomycosis. J. Eur. Acad. Dermatol. Venereol. 31, 1111-1118. doi: 10.1111/jdv.14212

Gupta, S., Maclean, M., Anderson, J. G., MacGregor, S. J., Meek, R. M. D., and Grant, M. H. (2015). Inactivation of micro-organisms isolated from infected lower limb arthroplasties using high-intensity narrow-spectrum (HINS) light. Bone Joint J. 97-B, 283-288. doi: 10.1302/0301-620X.97B2.35154

Halstead, F. D., Thwaite, J. E., Burt, R., Laws, T. R., Raguse, M., Moeller, R., et al. (2016). Antibacterial activity of blue light against nosocomial wound pathogens growing planktonically and as mature biofilms. Appl. Environ. Microbiol. 82, 4006-4016. doi: 10.1128/AEM.00756-16

Hamblin, M. R., Viveiros, J., Yang, C., Ahmadi, A., Ganz, R. A., and Tolkoff, M. J. (2005). Helicobacter pylori accumulates photoactive porphyrins and is killed by visible light. Antimicrob. Agents Chemother. 49, 2822-2827. doi: 10.1128/AAC. 49.7.2822-2827.2005

Hamcerencu, M., Desbrieres, J., Popa, M., Khoukh, A., and Riess, G. (2007). New unsaturated derivatives of xanthan gum: synthesis and characterization. Polymer 48, 1921-1929. doi: 10.1016/j.polymer.2007.01.048

Hayashi, S., Ishimoto, S., Wu, G., Wee, W., Rao, N., and McDonnell, P. (1997). Oxygen free radical damage in the cornea after excimer laser therapy. $\mathrm{Br} . J$. Ophthalmol. 81, 141-144. doi: 10.1136/bjo.81.2.141

Henry, C. A., Judy, M., Dyer, B., Wagner, M., and Matthews, J. L. (1995). Sensitivity of Porphyromonas and Prevotella species in liquid media to argon laser. Photochem. Photobiol. 61, 410-413. doi: 10.1111/j.1751-1097.1995.tb08 631.x

Hill, R., Healy, B., Holloway, L., Kuncic, Z., Thwaites, D., and Baldock, C. (2014). Advances in kilovoltage x-ray beam dosimetry. Phys. Med. Biol. 59:R183. doi: 10.1088/0031-9155/59/6/R183

Hiraku, Y., Ito, K., Hirakawa, K., and Kawanishi, S. (2007). Photosensitized DNA damage and its protection via a novel mechanism. Photochem. Photobiol. 83, 205-212. doi: 10.1562/2006-03-09-IR-840

Hull, M. C., Cambrea, L. R., and Hovis, J. S. (2005). Infrared spectroscopy of fluid lipid bilayers. Anal. Chem. 77, 6096-6099. doi: 10.1021/ac050990c

Imada, K., Tanaka, S., Ibaraki, Y., Yoshimura, K., and Ito, S. (2014). Antifungal effect of 405-nm light on Botrytis cinerea. Lett. Appl. Microbiol. 59, 670-676. doi: $10.1111 /$ lam. 12330

Jawetz, E. (1963). Antibiotics revisited: problems and prospects after two decades. Br. Med. J. 2, 951-955. doi: 10.1136/bmj.2.5363.951

Jin, J.-Y., Lee, S.-H., and Yoon, H.-J. (2010). A comparative study of wound healing following incision with a scalpel, diode laser or Er,Cr:YSGG laser in guinea pig oral mucosa: a histological and immunohistochemical analysis. Acta Odontol. Scand. 68, 232-238. doi: 10.3109/00016357.2010.492356

Karu, T. I. (2008). Mitochondrial signaling in mammalian cells activated by red and near-IR radiation. Photochem. Photobiol. 84, 1091-1099. doi: 10.1111/j.17511097.2008.00394.x

Kim, M.-J., and Yuk, H.-G. (2017). Antibacterial mechanism of 405-nanometer light-emitting diode against Salmonella at refrigeration temperature. Appl. Environ. Microbiol. 83:e02582-16. doi: 10.1128/AEM.02582-16

Kim, S., Kim, J., Lim, W., Jeon, S., Kim, O., Koh, J.-T., et al. (2013). In vitro bactericidal effects of 625,525, and $425 \mathrm{~nm}$ wavelength (Red, Green, and Blue) light-emitting diode irradiation. Photomed. Laser Surg. 31, 554-562. doi: 10.1089/pho.2012.3343

Kizhner, V., Krespi, Y. P., Hall-Stoodley, L., and Stoodley, P. (2011). Lasergenerated shockwave for clearing medical device biofilms. Photomed. Laser Surg. 29, 277-282. doi: 10.1089/pho.2010.2788

Kjeldstad, B. (1987). Different photoinactivation mechanisms in Propionibacterium acnes for near-ultraviolet and visible light. Photochem. Photobiol. 46, 363-366. doi: 10.1111/j.1751-1097.1987.tb04782.x

Kjeldstad, B., and Johnsson, A. (1986). An action spectrum for blue and near ultraviolet in activation of Propionibacterium acnes; with emphasis on a possible porphyrin photosensitization. Photochem. Photobiol. 43, 67-70. doi: 10.1111/j. 1751-1097.1986.tb05592.x

Koenig, K., Rueck, A. C., and Schneckenburger, H. (1992). Fluorescence detection and photodynamic activity of endogenous protoporphyrin in human skin. Opt. Eng. 31, 1470-1475. doi: 10.1117/12.57700
Kogkaki, E. A., Sofoulis, M., Natskoulis, P., Tarantilis, P. A., Pappas, C. S., and Panagou, E. Z. (2017). Differentiation and identification of grape-associated black aspergilli using Fourier transform infrared (FT-IR) spectroscopic analysis of mycelia. Int. J. Food Microbiol. 259, 22-28. doi: 10.1016/j.ijfoodmicro.2017. 07.020

Kohli, R., and Gupta, P. K. (2003). Irradiance dependence of the He-Ne laserinduced protection against UVC radiation in E. coli strains. J. Photochem. Photobiol. B 69, 161-167. doi: 10.1016/S1011-1344(03)00018-6

König, K., Teschke, M., Sigusch, B., Glockmann, E., Eick, S., and Pfister, W. (2000). Red light kills bacteria via photodynamic action. Cell. Mol. Biol. 46, 1297-1303.

Kumar, A., Ghate, V., Kim, M. J., Zhou, W., Khoo, G. H., and Yuk, H. G. (2016). Antibacterial efficacy of 405, 460 and $520 \mathrm{~nm}$ light emitting diodes on Lactobacillus plantarum, Staphylococcus aureus and Vibrio parahaemolyticus. J. Appl. Microbiol. 120, 49-56. doi: 10.1111/jam.12975

Kumar, S. R., and Imlay, J. A. (2013). How Escherichia coli tolerates profuse hydrogen peroxide formation by a catabolic pathway. J. Bacteriol. 195, 4569-4579. doi: 10.1128/JB.00737-13

Langkilde, F. W., and Svantesson, A. (1995). Identification of celluloses with Fourier-transform (FT) mid-infrared, FT-Raman and near-infrared spectrometry. J. Pharm. Biomed. Anal. 13, 409-414. doi: 10.1016/0731-7085(95) 01298-Y

Lembo, A. J., Ganz, R. A., Sheth, S., Cave, D., Kelly, C., Levin, P., et al. (2009). Treatment of Helicobacter pylori infection with intra-gastric violet light phototherapy - a pilot clinical trial. Lasers Surg. Med. 41, 337-344. doi: 10.1002/ lsm. 20770

Licata, M. E., Albanese, A., Campisi, G., Geraci, D. M., Russo, R., and Gallina, G. (2015). Effectiveness of a new method of disinfecting the root canal, using Er, Cr:YSGG laser to kill Enterococcus faecalis in an infected tooth model. Lasers Med. Sci. 30, 707-712. doi: 10.1007/s10103-013-1410-6

Ling, L. L., Schneider, T., Peoples, A. J., Spoering, A. L., Engels, I., Conlon, B. P., et al. (2015). A new antibiotic kills pathogens without detectable resistance. Nature 517, 455-459. doi: 10.1038/nature14098

Liu, T. M., Chen, H. P., Wang, L. T., Wang, J. R., Luo, T. N., Chen, Y. J., et al. (2009). Microwave resonant absorption of viruses through dipolar coupling with confined acoustic vibrations. Appl. Phys. Lett. 94:043902. doi: 10.1063/1. 3074371

Lubart, R., Lipovski, A., Nitzan, Y., and Friedmann, H. (2011). A possible mechanism for the bactericidal effect of visible light. Laser Ther. 20, 17-22. doi: $10.5978 /$ islsm.20.17

Lyon, B. R., and Skurray, R. (1987). Antimicrobial resistance of Staphylococcus aureus: genetic basis. Microbiol. Rev. 51, 88-134.

Maclean, M., Booth, M., Anderson, J., MacGregor, S., Woolsey, G., Coia, J., et al. (2013). Continuous decontamination of an intensive care isolation room during patient occupancy using $405 \mathrm{~nm}$ light technology. J. Infect. Prev. 14, 176-181. doi: $10.1177 / 1757177413483646$

Maclean, M., MacGregor, S. J., Anderson, J. G., and Woolsey, G. (2008a). Highintensity narrow-spectrum light inactivation and wavelength sensitivity of Staphylococcus aureus. FEMS Microbiol. Lett. 285, 227-232. doi: 10.1111/j.15746968.2008.01233.x

Maclean, M., MacGregor, S. J., Anderson, J. G., and Woolsey, G. A. (2008b). The role of oxygen in the visible-light inactivation of Staphylococcus aureus. J. Photochem. Photobiol. B 92, 180-184. doi: 10.1016/j.jphotobiol.2008. 06.006

Maclean, M., MacGregor, S. J., Anderson, J. G., and Woolsey, G. (2009). Inactivation of bacterial pathogens following exposure to light from a 405nanometer light-emitting diode array. Appl. Environ. Microbiol. 75, 1932-1937. doi: 10.1128/AEM.01892-08

Maity, J. P., Kar, S., Lin, C.-M., Chen, C.-Y., Chang, Y.-F., Jean, J.-S., et al. (2013). Identification and discrimination of bacteria using Fourier transform infrared spectroscopy. Spectrochim. Acta. A Mol. Biomol. Spectrosc. 116, 478-484. doi: 10.1016/j.saa.2013.07.062

Makdoumi, K., Goodrich, R., and Bäckman, A. (2017). Photochemical eradication of methicillin-resistant Staphylococcus aureus by blue light activation of riboflavin. Acta Ophthalmol. 95, 498-502. doi: 10.1111/aos.13409

Manaia, C. M. (2017). Assessing the risk of antibiotic resistance transmission from the environment to humans: non-direct proportionality between abundance, and risk. Trends Microbiol. 25, 173-181. doi: 10.1016/j.tim.2016.11.014 
Marti, H., Blenn, C., and Borel, N. (2015). The contribution of temperature, exposure intensity and visible light to the inhibitory effect of irradiation on acute chlamydial infection. J. Photochem. Photobiol. B 153, 324-333. doi: 10.1016/j.jphotobiol.2015.10.012

Martins, W. A., Polignano, G. A. C., Guimarães, O. R., Geller, M., Paoli, F., and Fonseca, A. S. (2015). Dichromatic laser radiation effects on DNA of Escherichia coli and plasmids. Laser Phys. 25:045603. doi: 10.1088/1054-660X/25/4/045603

Møller, K. I., Kongshoj, B., Philipsen, P. A., Thomsen, V. O., and Wulf, H. C. (2005). How Finsen's light cured lupus vulgaris. Photodermatol. Photoimmunol. Photomed. 21, 118-124. doi: 10.1111/j.1600-0781.2005.00159.x

Mussi, M. A., Gaddy, J. A., Cabruja, M., Arivett, B. A., Viale, A. M., Rasia, R., et al. (2010). The opportunistic human pathogen Acinetobacter baumannii senses and responds to light. J. Bacteriol. 192, 6336-6345. doi: 10.1128/JB.00 917-10

Narita, K., Asano, K., Morimoto, Y., Igarashi, T., Hamblin, M. R., Dai, T., et al. (2018). Disinfection and healing effects of 222-nm UVC light on methicillinresistant Staphylococcus aureus infection in mouse wounds. J. Photochem. Photobiol. B 178, 10-18. doi: 10.1016/j.jphotobiol.2017.10.030

Naumann, D., Barnickel, G., Bradaczek, H., Labischinski, H., and Giesbrecht, P. (1982). Infrared spectroscopy, a tool for probing bacterial peptidoglycan. Eur. J. Biochem. 125, 505-515. doi: 10.1111/j.1432-1033.1982.tb06711.x

Neu, H. C. (1992). The crisis in antibiotic resistance. Science 257, 1064-1073. doi: 10.1126/science.257.5073.1064

Nikandrov, V. V., Grätzel, C. K., Moser, J.-E., and Grätzel, M. (1997). Light induced redox reactions involving mammalian ferritin as photocatalyst. J. Photochem. Photobiol. B 41, 83-89. doi: 10.1016/S1011-1344(97)00085-7

Nitzan, Y., Salmon-Divon, M., Shporen, E., and Malik, Z. (2004). ALA induced photodynamic effects on Gram positive and negative bacteria. Photochem. Photobiol. Sci. 3, 430-435. doi: 10.1039/B315633H

Nitzan, Y., Shainberg, B., and Malik, Z. (1987). Photodynamic effects of deuteroporphyrin on Gram-positive bacteria. Curr. Microbiol. 15, 251-258. doi: 10.1007/BF01589376

Ramakrishnan, P., Maclean, M., MacGregor, S. J., Anderson, J. G., and Grant, M. H. (2014). Differential sensitivity of osteoblasts and bacterial pathogens to 405$\mathrm{nm}$ light highlighting potential for decontamination applications in orthopedic surgery. J. Biomed. Opt. 19, 105001-105001. doi: 10.1117/1.JBO.19.10.10 5001

Ramakrishnan, P., Maclean, M., MacGregor, S. J., Anderson, J. G., and Grant, M. H. (2016). Cytotoxic responses to $405 \mathrm{~nm}$ light exposure in mammalian and bacterial cells: involvement of reactive oxygen species. Toxicol. In Vitro 33, 54-62. doi: 10.1016/j.tiv.2016.02.011

Richardson, T. B., and Porter, C. D. (2005). Inactivation of murine leukaemia virus by exposure to visible light. Virology 341, 321-329. doi: 10.1016/j.virol.2005. 07.025

Ritter, M. A., Olberding, E. M., and Malinzak, R. A. (2007). Ultraviolet lighting during orthopaedic surgery and the rate of infection. J. Bone Joint Surg. Am. 89, 1935-1940. doi: 10.2106/JBJS.F.01037

Rocha Teixeira, G., da Silva Marciano, R., da Silva Sergio, L. P., Castanheira Polignano, G. A., Roberto Guimarães, O., Geller, M., et al. (2014). Infrared laser effects at fluences used for treatment of dentin hypersensitivity on DNA repair in Escherichia coli and plasmids. Opt. Laser Technol. 64, 46-52. doi: 10.1016/j.optlastec.2014.04.023

Russell, A. (2003). Biocide use and antibiotic resistance: the relevance of laboratory findings to clinical and environmental situations. Lancet Infect. Dis. 3, 794-803. doi: 10.1016/S1473-3099(03)00833-8

Saenz, N., Sánchez, M., Gálvez, N., Carmona, F., Arosio, P., and Dominguez-Vera, J. M. (2016). Insights on the (auto)photocatalysis of ferritin. Inorg. Chem. 55, 6047-6050. doi: 10.1021/acs.inorgchem.6b00547

Sailer, R., Strauss, W. S. L., König, K., Rück, A., and Steiner, R. (1997). Correlation between porphyrin biosynthesis and photodynamic inactivation of Pseudomonas aeruginosa after incubation with 5-aminolaevulinic amid. J. Photochem. Photobiol. B 39, 236-242. doi: 10.1016/S1011-1344(96)00 019-X

Schroeder, M., Brooks, B. D., and Brooks, A. E. (2017). The complex relationship between virulence and antibiotic resistance. Genes 8:39. doi: 10.3390/ genes 8010039

Shumilina, E., Dobrovolska, O., Conte, R. D., Holen, H. W., and Dikiy, A. (2014). Competitive cobalt for zinc substitution in mammalian methionine sulfoxide reductase B1 overexpressed in E. coli: structural and functional insight. J. Biol. Inorg. Chem. 19, 85-95. doi: 10.1007/s00775-013-1064-7

Song, K., Mohseni, M., and Taghipour, F. (2016). Application of ultraviolet lightemitting diodes (UV-LEDs) for water disinfection: a review. Water Res. 94, 341-349. doi: 10.1016/j.watres.2016.03.003

Takeshita, K., Shibato, J., Sameshima, T., Fukunaga, S., Isobe, S., Arihara, K., et al. (2003). Damage of yeast cells induced by pulsed light irradiation. Int. J. Food Microbiol. 85, 151-158. doi: 10.1016/S0168-1605(02)00509-3

Tanaka, M., Kinoshita, M., Yoshihara, Y., Shinomiya, N., Seki, S., Nemoto, K., et al. (2011). Photodynamic therapy using intra-articular photofrin for murine MRSA arthritis: biphasic light dose response for neutrophilmediated antibacterial effect. Lasers Surg. Med. 43, 221-229. doi: 10.1002/1sm. 21037

Tanzi, E. L., Lupton, J. R., and Alster, T. S. (2003). Lasers in dermatology: four decades of progress. J. Am. Acad. Dermatol. 49, 1-34. doi: 10.1067/mjd.2003.582

Tidwell, J. E., Dawson-Andoh, B., Adedipe, E. O., Nkansah, K., and Dietz, M. J. (2015). Can near-infrared spectroscopy detect and differentiate implantassociated biofilms? Clin. Orthop. Relat. Res. 473, 3638-3646. doi: 10.1007/ s11999-015-4497-1

Tomb, R. M., Maclean, M., Coia, J. E., MacGregor, S. J., and Anderson, J. G. (2017). Assessment of the potential for resistance to antimicrobial violetblue light in Staphylococcus aureus. Antimicrob. Resist. Infect. Control 6:100. doi: 10.1186/s13756-017-0261-5

Tschowri, N., Busse, S., and Hengge, R. (2009). The BLUF-EAL protein YcgF acts as a direct anti-repressor in a blue-light response of Escherichia coli. Genes Dev. 23, 522-534. doi: 10.1101/gad.499409

Tsiodras, S., Gold, H. S., Sakoulas, G., Eliopoulos, G. M., Wennersten, C., Venkataraman, L., et al. (2001). Linezolid resistance in a clinical isolate of Staphylococcus aureus. Lancet 358, 207-208. doi: 10.1016/S0140-6736(01) 05410- 1

van der Meulen, F. W., Ibrahim, K., Sterenborg, H. J., Alphen, L. V., Maikoe, A., and Dankert, J. (1997). Photodynamic destruction of Haemophilus parainfluenzae by endogenously produced porphyrins. J. Photochem. Photobiol. B 40, 204-208. doi: 10.1016/S1011-1344(97)00057-2

Vila, J., Ruiz, J., Marco, F., Barcelo, A., Goñi, P., Giralt, E., et al. (1994). Association between double mutation in gyrA gene of ciprofloxacin-resistant clinical isolates of Escherichia coli and MICs. Antimicrob. Agents Chemother. 38, 2477-2479. doi: 10.1128/AAC.38.10.2477

Vojisavljevic, V., Pirogova, E., and Cosic, I. (2007). The effect of electromagnetic radiation $(550-850 \mathrm{~nm})$ on 1-lactate dehydrogenase kinetics. Int. J. Radiat. Biol. 83, 221-230. doi: 10.1080/09553000701227565

von Wintersdorff, C. J., Penders, J., van Niekerk, J. M., Mills, N. D., Majumder, S., van Alphen, L. B., et al. (2016). Dissemination of antimicrobial resistance in microbial ecosystems through horizontal gene transfer. Front. Microbiol. 7:173. doi: $10.3389 /$ fmicb. 2016.00173

Vural, E., Winfield, H. L., Shingleton, A. W., Horn, T. D., and Shafirstein, G. (2008). The effects of laser irradiation on Trichophyton rubrum growth. Lasers Med. Sci. 23, 349-353. doi: 10.1007/s10103-007-0492-4

Wainwright, M., Maisch, T., Nonell, S., Plaetzer, K., Almeida, A., Tegos, G. P., et al. (2016). Photoantimicrobials-are we afraid of the light? Lancet Infect. Dis. 17, e49-e55. doi: 10.1016/S1473-3099(16)30268-7

Wang, J., Kim, K. H., Kim, S., Kim, Y. S., Li, Q. X., and Jun, S. (2010). Simple quantitative analysis of Escherichia coli K-12 internalized in baby spinach using Fourier transform infrared spectroscopy. Int. J. Food Microbiol. 144, 147-151. doi: 10.1016/j.ijfoodmicro.2010.09.013

Wang, J., Wei, J., Su, S., and Qiu, J. (2015). Novel fluorescence resonance energy transfer optical sensors for vitamin B 12 detection using thermally reduced carbon dots. New J. Chem. 39, 501-507. doi: 10.1039/C4NJ0 0538D

Wang, Y., Wu, X., Chen, J., Amin, R., Lu, M., Bhayana, B., et al. (2016). Antimicrobial blue light inactivation of Gram-negative pathogens in biofilms: in vitro and in vivo studies. J. Infect. Dis. 213, 1380-1387. doi: 10.1093/infdis/ jiw070

Wekhof, A. (2000). Disinfection with flash lamps. PDA J. Pharm. Sci. Technol. 54, 264-276.

Whitfield, C. (2006). Biosynthesis and assembly of capsular polysaccharides in Escherichia coli. Annu. Rev. Biochem. 75, 39-68. doi: 10.1146/annurev.biochem. 75.103004 .142545 
Wigle, J. C., Holwitt, E. A., Estlack, L. E., Noojin, G. D., Saunders, K. E., Yakovlev, V. V., et al. (2014). No effect of femtosecond laser pulses on M13, E. coli, DNA, or protein. J. Biomed. Opt. 19:015008. doi: 10.1117/1.JBO.19.1. 015008

Yang, P., Wang, N., Wang, C., Yao, Y., Fu, X., Yu, W., et al. (2017). 460 nm visible light irradiation eradicates MRSA via inducing prophage activation. J. Photochem. Photobiol. B 166, 311-322. doi: 10.1016/j.jphotobiol.2016.12.001

Yang, S.-C., Lin, H.-C., Liu, T.-M., Lu, J.-T., Hung, W.-T., Huang, Y.-R., et al. (2015). Efficient structure resonance energy transfer from microwaves to confined acoustic vibrations in viruses. Sci. Rep. 5:18030. doi: 10.1038/ srep 18030

Zhu, H., Kochevar, I. E., Behlau, I., Zhao, J., Wang, F., Wang, Y., et al. (2017). Antimicrobial blue light therapy for infectious keratitis: ex vivo and in vivo studies. Invest. Ophthalmol. Vis. Sci. 58, 586-593. doi: 10.1167/iovs.16-20272
Zipperer, A., Konnerth, M. C., Laux, C., Berscheid, A., Janek, D., Weidenmaier, C., et al. (2016). Human commensals producing a novel antibiotic impair pathogen colonization. Nature 535, 511-516. doi: 10.1038/nature18634

Conflict of Interest Statement: The authors declare that the research was conducted in the absence of any commercial or financial relationships that could be construed as a potential conflict of interest.

Copyright $\odot 2018$ Gwynne and Gallagher. This is an open-access article distributed under the terms of the Creative Commons Attribution License (CC BY). The use, distribution or reproduction in other forums is permitted, provided the original author(s) and the copyright owner are credited and that the original publication in this journal is cited, in accordance with accepted academic practice. No use, distribution or reproduction is permitted which does not comply with these terms. 